Original Paper

\title{
Chlorine Behavior During Low-Temperature Pyrolysis Process at the First Stage of the Two-Stage Fluidized-Bed Waste Incinerator
}

\author{
Hidetoshi Y AMAMOTO *1, Masamichi A SANO *2, Tatsuya IKEDA *1, \\ Tomomasa TAGUCHI *1, and Takao HARA *1 \\ (Received April 2, 2003)
}

\begin{abstract}
流動床二段廃棄物燃焼炉の第一段低温熱分解過程における塩素挙動 山本英寿*1，浅野昌道*2，池田辰也*1，田口智将*1，原 孝夫*1
\end{abstract}

The aim of this study is to research the mechanism of dechlorination for low-temperature pyrolysis process not only by establishing the material and calorific balance at the first stage of the two-stage fluidized-bed waste incinerator but also by revealing the behavior of chlorine towards products formed in the pyrolysis. The pyrolysis experiments have been performed using wood chips containing poly (vinyl chloride) in a 5:1 weight ratio as a model refuse-feed. The feed is pyrolyzed with and without catalyst (disposable iron sulfide catalyst), as well as under the presence of low oxygen concentration $(5.7 \mathrm{vol} \%)$ at $360-420^{\circ} \mathrm{C}$. The acidic and acid-free fractions separated by the treatment with an anion exchange resin from tar component are characterized by means of spectroscopic techniques (FT-i.r., ${ }^{1} \mathrm{H}-\mathrm{NMR}$ and ${ }^{13} \mathrm{C}-\mathrm{NMR}$ ) and ultimate analysis, comparing to those from tar components formed by the pyrolysis of six different kinds of hydrocarbons and poly (vinyl chloride).

The results show that; (1) Calorific value of char retains more than $40 \%$ of the starting feed, which exceeds the process target for calorific balance between the first and second stage of the total incineration process. (2) More than $95 \%$ of chlorine involved in the feed is removed during pyrolysis and the dechlorinated char component ( $\mathrm{Cl}$ content: $0.4-0.8 \mathrm{wt} \%$ ) could be transferred into the second stage for the total system. (3) The presence of the catalyst in the pyrolysis plays an important role in the reduction of chlorophenols formed in the low-temperature pyrolysis process.

\section{Key Words}

Two-stage fluidized-bed incinerator, Low-temperature pyrolysis, Chlorine behavior, Dioxins-precursor, Calorific balance

\section{1. 序 論}

わが国は地球温暖化防止の観点から，都市ごみ焼却排熱の 効率的な有効利用を推進中である。この状況下で, ごみ発電 効率は，焼却時の燃焼ガス中に含まれる塩化水素等の腐食性 ガスの問題から，約 $10 \%$ と低くとどまっており，その改善が 求められている1)。さらに，燃焼ガス中にはダイオキシン類を 含み，その排出量の約 $80 \%$ が都市ごみの焼却設備から排出さ れていることから，厳しい排出規制を達成するための技術開 発が重要な課題となっている ${ }^{2)}$ 。

* 1 Graduate School of Engineering, Yokohama National University

79-5 Tokiwadai, Hodogaya-ku, Yokohama 240-8501, Japan

* 2 Mitsubishi Heavy Industries, Ltd.

1-8-1 Sachiura, Kanazawa-ku, Yokohama 236-8515, Japan
これらの社会的要請に応えるべく，近年注目を浴びている のが廃棄物の熱分解・ガス化溶融システムである ${ }^{34} 4$ 。この技 術の一つとして, 流動床二段廃棄物燃焼システムがあり ${ }^{3)}$, 筆 者らの研究室はこの構成部分である熱分解過程について要素 研究を行った。このシステムの特徵は, 外部エネルギーを必 要とせず，ごみの自己熱で熱分解・燃焼から灰溶融までを一 貫して行い, ダイオキシン類の環境対策や, 高効率発電, 直 接灰溶融処理，排ガス量極少化等を同時に解決する高度な次 世代型廃裹物焼却技術の実現を目指すものである。

\footnotetext{
* 1 横浜国立大学大学院 工学研究科 于 240-8501 横浜市保土ケ谷区常盤台 79-5

* 2 三菱重工業株式会社 技術本部横浜研究所 干 236-8515 横浜市金沢区幸浦 1-8-1
} 
本システムの基本コンセプトをFig. 1 に示す ${ }^{33)}$ 5) このシス テムは第一段低温熱分解過程 (以下，第一段熱分解炉)，第二 段高温高速循環型流動床燃焼炉(第二段燃焼炉)，堅型旋回灰 溶融炉 (溶融炉)および熱回収部等から構成される。まず，都 市ごみを，第一段熱分解炉で熱分解 $\left(350 \sim 450^{\circ} \mathrm{C}\right)$ し，脱塩 素率が $95 \%$ 以上のクリーンなチャー（固形生成物）に転換す る。ここでの熱源は，ごみを低酸素濃度䨌囲気下（5.7vol\%） で部分燃焼させて，その熱エネルギーを使用する。また，ご みは第二段燃焼炉からの循環砂 $\left(650 \sim 700^{\circ} \mathrm{C}\right)$ を燃焼用空気 で流動状態にしたところで投入される ${ }^{3)}$ 。次いで, 生成チャー を第二段燃焼炉で燃焼することにより $\left(850 \sim 950^{\circ} \mathrm{C}\right), 9.8 \mathrm{MPa}$, $500^{\circ} \mathrm{C}$ の過熱水蒸気を発生させ, 発電効率 $30 \%$ を達成すること を目標としている。一方，第一段熱分解炉からの熱分解ガス を利用して溶融炉で高温燃焼し（約 $1350 \sim 1400^{\circ} \mathrm{C}$ ), 灰中の ダイオキシン類を完全分解するとともに，灰を溶融スラグ化 し再利用する。この際の燃焼熱は廃熱ボイラで回収する。熱 分解ガス中と, 溶融炉からの燃焼ガス中に高濃度の $\mathrm{HCl}$ が存 在することに対しては, 耐酸性耐火材の採用(溶融炉) と, 燃 焼ガスを，使用条件が緩慢な飽和水蒸気回収部へ導入（廃熱 ボイラ）することにより， $\mathrm{HCl}$ 腐食を回避する ${ }^{3)} 。$

このプロセスの中で, 第一段熱分解炉では高い脱塩素率と, ダイオキシン類前駆体（クロロフェノール類）の低減除去を
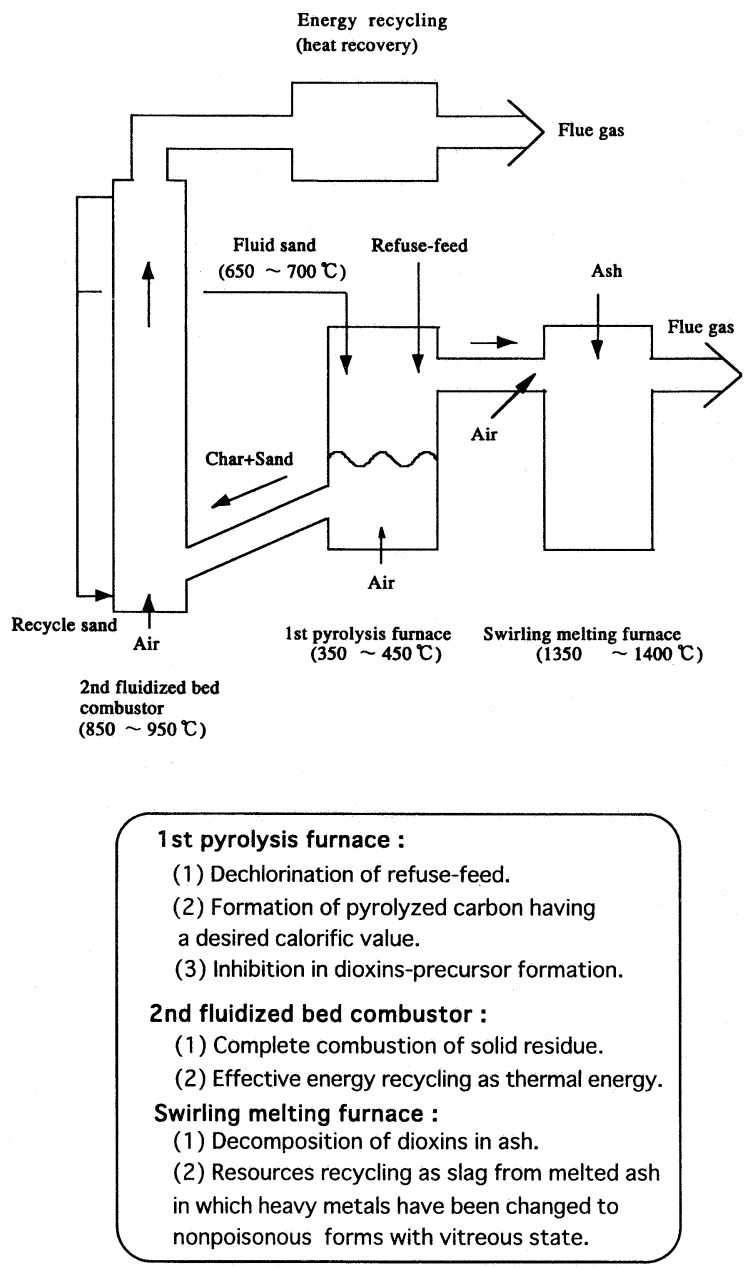

Fig. 1 Concept of new incineration system of refuse-feed

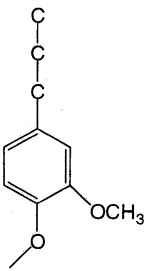

(1) Lignin* $^{*}$

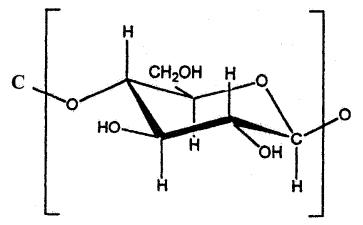

(2) Cellulose
Fig. 2 Structural model of skeletal substance contained in lignin and cellulose ( ${ }^{*}$ Phenolic phenylpropane unit)

達成しながら, チャーの保有熱量を第二段燃焼炉にバランス よく配分する必要がある。そこで本研究では, ごみモデル試 料を用いて第一段熱分解炬での物質収支と熱収支を検討し， 第一段熱分解炉と第二段燃焼炉の熱バランスを明らかにする ことを目的とした。次いで, 試料の熱分解時における塩素挙 動を検討することにより，第一段熱分解炉での脱塩素とその 反応機構について考察した。

本報では, 熱分解を, Fig. 1 に示すように低酸素下で部分 燃焼させながらその熱を利用しての分解を含むものと定義し た ${ }^{6)}$ 10)。熱分解実験は, 試料として木材チップとポリ塩化ビ ニル (PVC) との混合試料, および添加物として $50 \%$ 硫化鉄 触媒を用いた。これらを使用した理由は, 木材チップについ てはその中に含まれるリグニンの構造単位 ${ }^{11)}$ である, フェ ノール性フェニルプロパン誘導体 (Fig. 2) がダイオキシン類 前駆体の骨格を形成していると考えたためであり ${ }^{12)}$, PVCは 塩素源としてである。50\%硫化鉄触媒に関しては，これが存 在することによって, 熱分解生成物が改質され ${ }^{13)}$, 前駆体生 成の削減効果が期待できるので ${ }^{14)}$, このことを前提として, 触 媒存在下に㧍ける塩素分配挙動に及ぼす影響を明らかにする ためである。木材チップとPVCとの混合割合 (重量比 $5 ： 1$ ) は, 現在廃棄されている都市ごみの組成やそのカロリー（低 位発熱量, 以下 LHV と略記する; 約 $18900 \mathrm{~kJ} / \mathrm{kg}$ ) を考慮して 決定した ${ }^{15)}$ 。また, 反応物質 (モデル試料) である木材中の リグニン構造は複雑であり, その反応は多くの場合不均一系 反応として進行することから $11 \mathrm{a})$, 実験データの再現性に留意 して行った。

\section{1 試料，触媒および試薬等}

\section{2. 実 験}

\subsection{1 試料}

木材チップ (南洋材; 三菱重工業横浜研究所より入手) は, 破砕後，1〜2mmのサイズにふるい分けしたものを用いた。 PVCは, 半硬質ポリ塩化ビニル (直径 $5 \mathrm{~mm} \times$ 厚さ $2 \mathrm{~mm}$ ペ レット状； $\mathrm{Cl}$ 含有率， $45.4 \mathrm{wt} \%$; 三菱化成 $\mathrm{MKV}$ ) を，同様の 方法で 1 $2 \mathrm{~mm}$ のサズにふるい分けして使用した。また PVCの共存試料種として, 次の炭化水素化合物をそのまま使 用した：低密度ポリエチレン（LDPE：直径 $4 \mathrm{~mm} \times$ 厚さ 2 $\mathrm{mm}$; 旭化成), 高密度ポリエチレン (HDPE: TX-101A33S1; 直径 $3 \mathrm{~mm} \times$ 厚さ $2 \sim 3 \mathrm{~mm}$; ユニオンポリマー), 一般用ポ リスチレン (GPPS:HT-55; 縦 $2 \mathrm{~mm} \times$ 横 $3 \mathrm{~mm} \times$ 長さ $3.5 \mathrm{~mm}$; 三菱化成), 耐衝撃性ポリスチレン (HIPS:HT-58; 縦 $1.5 \mathrm{~mm} \times$ 
横 $3 \mathrm{~mm} \times$ 長さ $3.5 \mathrm{~mm}$; 三菱化成 $),$ 七ルロース $\left(\left(\mathrm{C}_{6} \mathrm{H}_{10} \mathrm{O}_{5}\right) \mathrm{n}\right.$ ： 微結晶, クロマトグラフイー用; Merck), リグニン（化学用 試薬, 粉体; 関東化学)。

\section{1 .2 触媒}

$50 \% \mathrm{FeS}$ 触媒（和光純薬・化学用試薬，灰黒色の固塊; min. $50 \%$ 残りは酸化鉄・単体硫黄等の不純物である; 以下触媒と 略記する）は，乳鉢で粉砕して用いた。

\section{1 .3 試薬等}

次の試薬は，特級品を購入してそのまま，または溶解・希 釈して使用した：0.2M NaOH 水溶液は，熱分解ガス中の $\mathrm{HCl}$ の吸収・捕集液として用い，0.1M AgNO3 溶液（容量分析用） は， $\mathrm{HCl}$ の定量に使用した。 $\mathrm{CCl}_{4}$ (min.99.5\%) は，塩素の吸 収に用いた。 $15 \% \mathrm{KI}$ 溶液， $0.01 \mathrm{M} \mathrm{Na} 2 \mathrm{~S}_{2} \mathrm{O}_{3}$ 標準液 (容量分析用) および $1 \%$ デンプンは，塩素の定量（ヨウ素還元滴定法）に 使用した。その他の試薬については市販の特級品をそのまま 用いた。

また空気は，濃硫酸で脱水・乾燥した圧縮空気を用い，窒 素ガスは，大陽東洋酸素社製の純度 $99.9995 \%$ 以上の圧縮窒素 を使用した。供給ガスは，上述の圧縮空気と窒素ガスを，そ れぞれ $0.05 \mathrm{MPa}$ の 2 次圧力に調整・保持した後，それぞれに 設置した精密ニードルバルブ付流量計（小島製作所製 RK1250 ; 誤差士 $0.5 \%$ 以内）により，酸素濃度が $5.7 \mathrm{vol} \%$ （容積 比:窒素 /空気 $=2.68)$ となるように混合した。石英ガラスウー ルは，日本石英硝子社製の純 $\mathrm{SiO}_{2}$ ，無アルカリのものを用い た。二酸化炭素（純度 $99.9 \%$ 以上）は，(株)川崎総合ガスセ ンターから購入した。

\section{2 試料調製}

ナスフラスコにメタノールを取り，試料（木材チップ $5.0 \mathrm{~g}$, PVC 1.0g）に対して $0.094 \sim 1.0 \mathrm{wt} \%$ （金属重量）の触媒を溶 解・懸濁させた後，試料を加え一昼夜浸せきし，試料を均質 化した。次いで，メタノールを留去し真空乾燥 $\left(35^{\circ} \mathrm{C}, 1 \mathrm{~h}\right)$ した後，乾燥後の試料重量から，添加触媒量を差し引いたも のを試料の正味重量とした。

\section{3 熱分解条件}

実験での熱分解条件をTable 1に示す。物質収支および熱収 支に影響を与えると考えられる，熱分解温度 $\left(360 \sim 420^{\circ} \mathrm{C}\right)$ と添加物（触媒の有無）の 2 因子を主として検討した。実験 は，熱分解温度を設定温度士 $5{ }^{\circ} \mathrm{C}$ に制御しながら大気圧下で 行い $(1 \mathrm{~h})$, 供給ガス $\left(\mathrm{O}_{2} 5.7 \mathrm{vol} \%\right)$ は $7 \mathrm{ml} / \mathrm{min}$ （線速度 7 $\left.\times 10^{-2} \mathrm{~cm} / \mathrm{s}\right)$ の一定流量とした。なお，熱分解温度と酸素濃 度は，第一段熱分解炉と第二段燃焼炬に扔ける物質収支と熱 収支の予備実験結果をふまえ，第一段熱分解炉の炉床が所定 の温度を保持するように設定した。また，熱分解時間は試料 中の固体有機物間の脱塩素化および塩素化を，十分に促進さ せるために必要な反応時間を考慮して決定した ${ }^{16) 。 ~}$
Table 1 Reaction conditions for pyrolysis of model refuse-feed

\begin{tabular}{l|l}
\hline Model refuse-feed & (a) Wood chips + (b) PVC (polyvinyl
\end{tabular} chloride) (Ratio $\mathrm{a} / \mathrm{b}=5.0$ by weight)

\begin{tabular}{l|l}
\hline Temperature & $360,380,400,420^{\circ} \mathrm{C}$ \\
\hline Pressure & Atmospheric \\
\hline Reaction period & 1 hour \\
\hline Gas stream & $\mathrm{N}_{2}+$ Air $\left(\mathrm{O}_{2} 5.7 \mathrm{vol} \%\right)$ \\
\hline Gas flow rate & $\begin{array}{l}7 \mathrm{ml} / \mathrm{min} \\
\left.\text { (Linear velocity }: 7 \times 10^{-2} \mathrm{~cm} / \mathrm{s}\right)\end{array}$ \\
\hline Catalyst species added & $\begin{array}{l}\text { Iron (II) sulfide }(\text { disposable iron } \\
\text { sulfide) }(\text { Assay }: \text { min. } 50 \%)\end{array}$ \\
\hline
\end{tabular}

Catalyst quantity added $0.094 \sim 1.0 \mathrm{wt} \%$ of iron content relative to amount of model refuse-feed

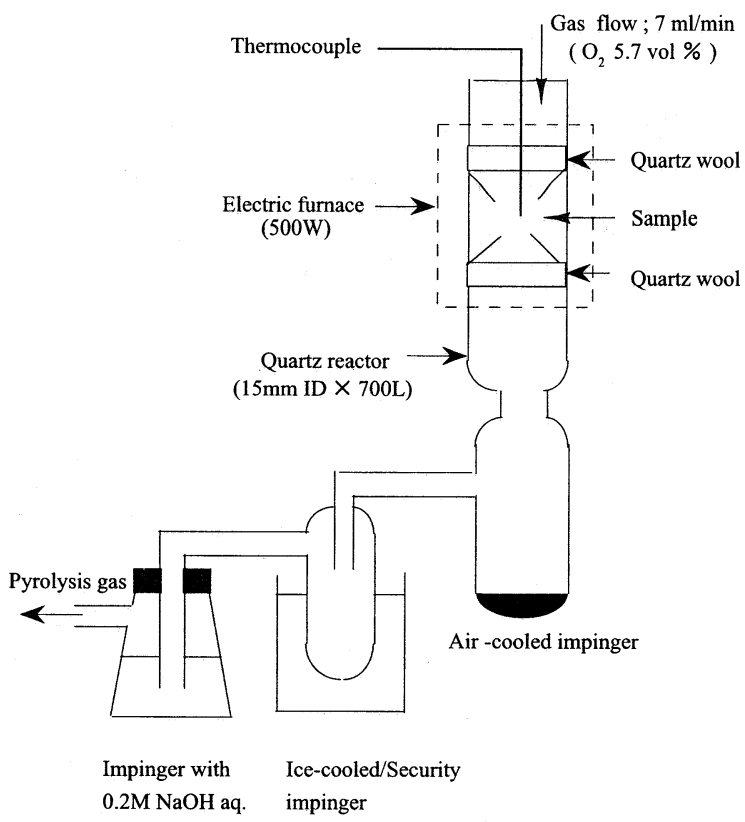

Fig. 3 Experimental apparatus for pyrolysis experiments

\section{4 熱分解実験装置と操作}

\section{4 .1 実験装置}

熱分解実験装置を Fig. 3 に示す。この装置は, 電気管状炉 および流通式反応管 (石英ガラス; 内径 $15 \mathrm{~mm} \times$ 長さ $700 \mathrm{~mm}$ ) の内部中央部に保護管付きの熱電対 (SUS316; 外径 $1.6 \mathrm{~mm} \times$ 長さ $500 \mathrm{~mm}$ ）を備えたものから構成される。熱分解温度の計 測および制御は，アナログ温度計測制御器 (SHIMADEN 製) を用いた。雾囲気ガスは，電気炉内の反応管内を通過しサン プル充填層に到達する間に，設定熱分解温度まで到達するこ とができた。

\section{4 .2 実験操作}

実験は縦型および横型の 2 方式で行った。木材チップとの 熱分解は縦型装置を用いて行った(Fig. 3)。まず反応管内を窒 素ガスで置換した後，乾燥試料（6g を正確に秤量したもの） を反応管の中央部に充填した。充填の際に石英ガラスウール (約 $0.2 \mathrm{~g})$ で試料を上下から挟んで固定した。試料充填後，供 給ガスで管内を置換した。次に，炉内中央部に試料を充填し 
た反応管を挿入し，急速に所定の温度にまで加熱した（反応 管择入開始約 $7 \sim 8$ 分以内)。設定温度 $\left(360 \sim 420^{\circ} \mathrm{C}\right)$ に達 した後，60分間熱分解を行った。一方，炭化水素化合物試料 との熱分解は横型装置を用いて行った。この場合は，まず試 料 (炭化水素化合物 $2.5 \mathrm{~g}$, PVC $0.5 \mathrm{~g}$ ：それぞれ正確に秤量した もの）を封入管（石英ガラス；内径 $9.5 \mathrm{~mm} \times$ 長さ $140 \mathrm{~mm}$ ）に

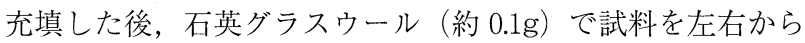
挟んで固定した。次いでこの試料封入管を反応管の内部中央 部に設置し，そのあと熱電対を試料封入管の前流側先端に備 えた。その他の操作については木材チップの場合と同様にし て行った。

\section{5 熱分解生成物の回収方法}

実験で得られた熱分解生成物の各成分は，Fig. 4に従って回 収した：

(1)液状生成物は，反応管（充填層の下部）付着成分中の液 状成分と，各トラップにおける回収成分の総和とした。

(2)チャー成分は，反応管中に残った熱分解残渣から触媒量 を差し引いたものに，上述反応管付着成分中の熱分解残渣を 加えたものとした。

(3)夕ール成分は，液状生成物をテトラヒドロフラン (THF) に溶解し $\mathrm{MgSO}_{4}$ 無水物を加えて脱水した後, THFを完全留去 し残ったものとした。したがって，タール成分は，熱分解反 応によって生成したTHF可溶な有機成分を意味するが，THF 留去過程で低沸点成分は散逸している。

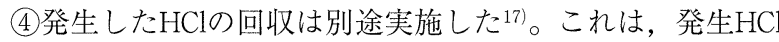
ガスの一部が，液状生成物中に塩酸として存在しており，発 生 $\mathrm{HCl}$ と液状生成物の物質収支を同時に検討できないためで ある。発生した $\mathrm{HCl}$ は， $0.2 \mathrm{M} \mathrm{NaOH}$ 水溶液で吸収・捕集した 後，30\% $\mathrm{H}_{2} \mathrm{O}_{2}$ 水 $(1 \mathrm{ml})$ によりアルデヒドなどの還元性有機 物の酸化を行った。次いで $2 \mathrm{M} \mathrm{HNO}_{3}$ による酸処理 $(\mathrm{pH} 2)$ と ジエチルエーテル抽出による有機不純物の除去を行った後, $0.1 \mathrm{M} \mathrm{AgNO} 3$ 溶液を加え塩化銀として定量した。

(5)塩素ガスは, $\mathrm{CCl}_{4}(80 \mathrm{ml} \times 2)$ で吸収した後, ヨウ素還
元滴定法にて定量した ${ }^{18)}$ 。

(6)ガス成分は，試料重量からチャー成分と液状生成物を差 し引いたものであり， $\mathrm{HCl}$ を含むものとした。

\section{6 タール成分の分離方法と測定方法}

2.6.1 ソックスレー抽出

熱分解で生成したタール成分をベンゼンでソックスレー抽 出した後, ベンゼンを留去し減圧乾燥した。

\section{6 .2 陰イオン交換樹脂による分離}

ベンゼン抽出成分中に含まれる酸性成分を，陰イオン交換 樹脂（Rohm \& Hars 社製 Amberlite IRA-904）を用いて分離し た ${ }^{19)}{ }^{20)}$ 。樹脂上に吸着した成分 (酸性成分) は, $\mathrm{CO}_{2}$ 飽和义 夕ノール溶液およびギ酸 $(5 \mathrm{wt} \%) / \mathrm{THF}$ 溶液をこの順で溶 離液として用いることにより回収した。ベンゼン溶出成分 (非 酸性成分）にフェノール性水酸基が残存する場合には，再度 この操作を繰り返した。

\subsection{3 測定方法}

希薄溶液IRスペクトル (以下IRと略記する) 測定は, JASCO FT/IR-5300 赤外分光光度計を用いて行った $\left(0.5 \sim 1.0 \mathrm{~g} / \mathrm{dm}^{3}\right.$, $\mathrm{CS}_{2}$ 溶媒， $2 \mathrm{~cm} \mathrm{KBr}$ 液体セル) ${ }^{20)}$ 。 ${ }^{1} \mathrm{H}-\mathrm{NMR}$ スペクトルおよび ${ }^{13} \mathrm{C}-\mathrm{NMR}$ は日本電子製JEOL JNM-EX-270 権測周波数: ${ }^{1} \mathrm{H}(270$ $\left.\mathrm{MHz}) ;{ }^{13} \mathrm{C}(67.8 \mathrm{MHz})\right\}$ を用いて測定した。測定溶媒はTMS入 り $\mathrm{CDCl}_{3}$ を用いた。

\section{7 熱分解生成物の性状分析}

チャーおよび，タール成分とその分離成分の元素の定量は， “石炭類及びコークス類の元素分析方法” (JIS M 8813-1988) によった。

\section{3. 結果と考察}

3.1 熱分解状況観察結果

実験中の主な観察結果は次のとおりであった：

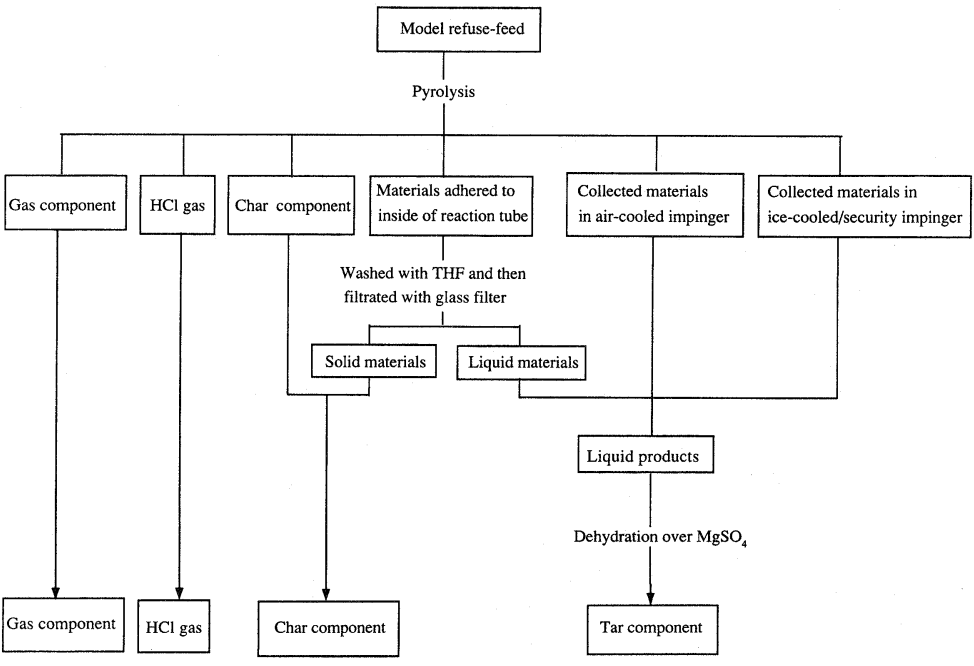

Fig. 4 Separation flow of products formed by pyrolysis of model refuse-feed 
(1)試料（木材チップ+ PVC）の熱分解で発生した分解ガス を，前述のヨウ素還元滴定法で確認した結果，本実験では塩 素ガスの発生は認められなかった。このことから，本熱分解 実験で発生したガスは，主として $\mathrm{HCl}$ ガスであり， $\mathrm{Cl}_{2}$ ガスの 発生はなかったことを確認した。また，この発生 $\mathrm{HCl}$ ガスは 上述液状生成物中に塩酸として約 $10 \mathrm{wt} \%$ の濃度で存在してお り，このことは，PVC 中の塩素の $44 \sim 55 \%$ 分が液状生成物 中に塩酸の形態で分配されていることを意味している。

(2)夕ール成分の物性は，触媒存在の場合は，単純な熱分解 と比較して粘性が低かった。これは，触媒作用により夕ール 成分の一部が軽質化したためであると考えられる。

\section{2 物質収支}

本節では，熱分解システムを検討する上で必要となる構成 要素を，熱分解生成物に㧍ける各成分の収率（重量％）の形 で表した ${ }^{21)}$ 。ここで得た物質収支は，熱収支と，熱分解生成 物への塩素分配挙動の検討における基礎データとした。

\subsection{1 実験結果}

実験に先立ち，試料（木材チップ+PVC）を使用した一連 の熱分解実験の中で，同一条件における 5 回のデー夕の再現 性を確認した(Table 2)。この結果，各収率における分散度の 変動係数 (相対標準偏差) は $2.4 \sim 6.5 \%$ ありり, 本実験で再 現性を論じる各成分については，変動係数が小さく満足す心゙ きものと判断した。

そこで，本実験では（Table 1)， $360^{\circ} \mathrm{C}$ おび $420^{\circ} \mathrm{C}$ におけ る触媒有の実験については 2 回以上の実験值の平均值を使用 し，それ以外については 1 回の実験值を用いて検討した。物 質収支は触媒添加有無の 2 条件について検討し，この実験結 果をFig. 5に示す。これは，試料重量に対するチャー成分，液 状生成物，ガス $(\mathrm{HCl}$ を含む) および夕ール成分の分解温度に 対する収率である。タール成分は液状生成物を脱水し低沸点

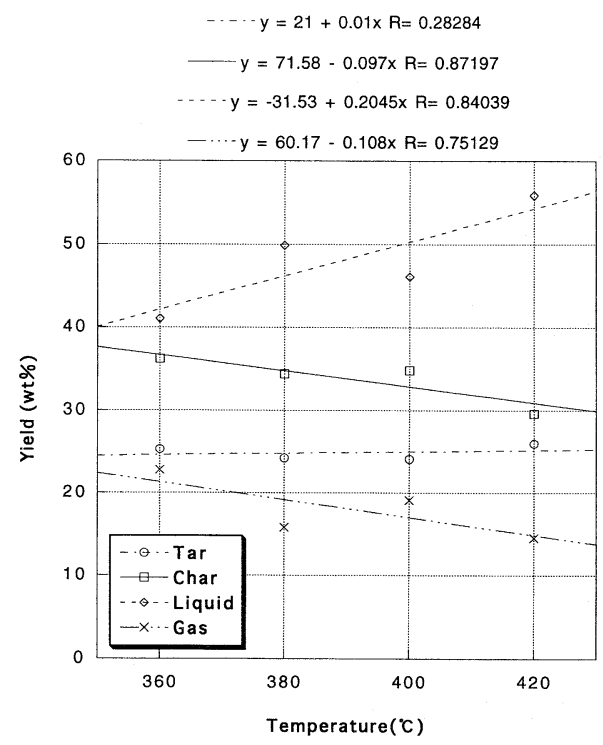

(1) Without catalyst
成分を留去したものであるので，タールを除いた他の 3 成分 で100\%とした。

\section{2 .2 考察}

各成分の収率と分解温度との関連の深さを評価するため， 2 条件について相関係数 $(\mathrm{R})$ を求めたところ，線形モデルの場 合が最も強い相関が見られた。この結果を回帰式とともに Fig. 5 に示す。

これより，見いだされた特徵点は次のとおりである：触媒 が存在すると，全体的に試料の分解反応が促進され，とくに 高温度領域になるにつれてチャー収率の減少に伴う液状生成 物の増大が見られた。また夕ール成分の収率は，無触媒では 分解温度によらず変化がなかったのに対し $(\mathrm{R}=0.3)$, 触媒存 在下ではやや増大した $(\mathrm{R}=0.6)$ 。このように触媒が存在する と，触媒活性の発現による物質収支への影響が $10 \%$ 程度見ら れた 22)。この結果は，触媒存在下での熱分解実験の観察結果 （タール成分の一部軽質化）とも一致しており（3.1節），また，

Table 2 Reproducibility of material balances in the pyrolysis of medel refuse-feed

\begin{tabular}{c|c|c|c|c}
\hline \multirow{2}{*}{ Run* } & \multicolumn{4}{|c}{ Yields (wt\%) } \\
\cline { 2 - 5 } & Tar & Char & Liquid & Gas \\
\hline 1 & 20.6 & 33.4 & 48.2 & 18.4 \\
2 & 24.3 & 31.6 & 50.3 & 18.1 \\
3 & 22.5 & 32.7 & 49.2 & 18.1 \\
4 & 23.8 & 31.5 & 51.3 & 17.2 \\
5 & 23.8 & 30.8 & 50.3 & 18.9 \\
\hline Means (wt\%) & 23.0 & 32.0 & 49.9 & 18.1 \\
Standard deviations (wt\%) & 1.5 & 1.0 & 1.2 & 0.6 \\
Coefficients of variation (wt\%) & 6.5 & 3.1 & 2.4 & 3.3 \\
\hline
\end{tabular}

* Experiments were carried out with a model refuse-feed, which is composed of wood chips and PVC in a 5:1 weight ratio. The feed was pyrolyzed for $1 \mathrm{~h}$ with FeS catalyst and in the presence of oxygen $(5.7 \mathrm{vol} \%)$ at $360^{\circ} \mathrm{C}$.

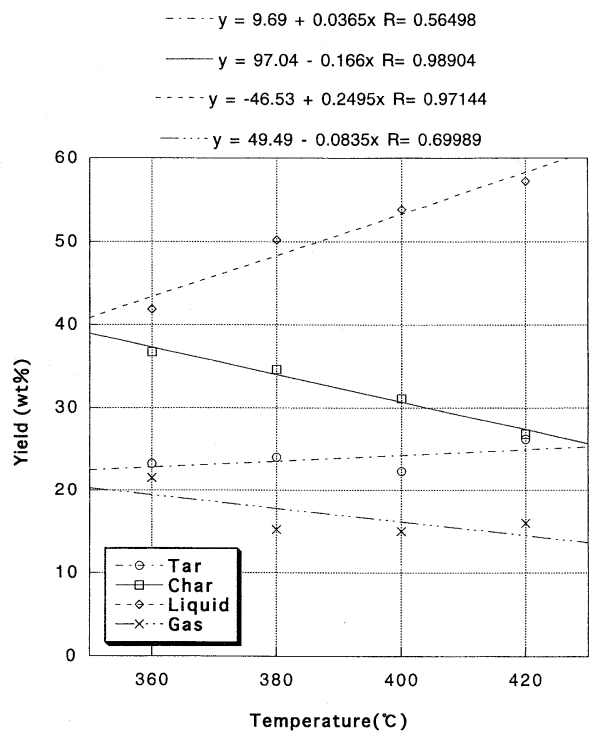

(2) With catalyst ${ }^{\star}$

Fig. 5 Product yields from pyrolysis experiments of model refuse-feed (*Disposable iron sulfide (1.0 wt\%)) 
同様な温度領域における石炭質の熱分解反応における種々の 金属塩の添加効果に関して得られた結果と一致している ${ }^{23) 。 ~}$

\section{3 熱収支}

上述の物質収支を基にチャー成分の保有熱量を求めること により，第一段熱分解炉と第二段燃焼炉の熱収支を検討した。 ここでは，Fig. 1に示したプロセスにおいて，第一段熱分解炉 でごみを熱分解することにより，ごみの発熱量のうちその 40 \%以上の熱量はチャー成分に分配させて第二段燃焼炉に供給 することを目標とした ${ }^{3)}$ 5)。

\subsection{1 チャー成分の保有エネルギー}

\section{(1) 元素分析值}

チャー成分の元素分析值をTable 3に示す。表中には，同一 の反応条件で生成したタール成分の元素分析值も併せて示し た。また，両成分中の窒素含有量は $0 \sim 0.3 \mathrm{wt} \%$ 程度と小さく， 本研究では解析対象とはしなかった。

\section{（2）発熱量の算出}

本論文では，一般に熱分解炬の設計で使用されるLHVを用 いて考察した。また都市ごみの適用に最も近いとされ，LHV で示されるSteuerの式についても併せて検討した。発熱量の 算出は，次の計算式によった。
·低位発熱量 ${ }^{24)}$

$$
\mathrm{LHV}=33900 \cdot \mathrm{c}+120000 \cdot \mathrm{h}-17800 \cdot \mathrm{O}
$$$$
+10500 \cdot \mathrm{s}-2500 \cdot \mathrm{W}[\mathrm{kJ} / \mathrm{kg}]
$$

ここで, 元素分析值より $1 \mathrm{~kg}$ 中のc炭素, h水素, o (diff.) 酸 素, $\mathrm{s}$ 硫黄, $\mathrm{w}$ 水分量 $(\mathrm{kg})$ とした。なお, チャー成分中の水 分量 $\mathrm{W}$ は 0 とし, またO (diff.) 酸素は, チャー成分の元素分 析值および灰分含有量の分析值から求めた。

$\cdot$ Steuer の式 ${ }^{15)}\left(\mathrm{O} / \mathrm{H}_{2} \mathrm{O}\right.$ 結合比 $\mathrm{k}=1 / 2$ の場合 $)$

$$
\begin{aligned}
\mathrm{LHV}= & 339(\mathrm{C}-3 / 8 \cdot \mathrm{O})+239 \times 3 / 8 \cdot \mathrm{O} \\
& +1440(\mathrm{H}-1 / 16 \cdot \mathrm{O}) \\
& +94 \cdot \mathrm{S}-25(9 \mathrm{H}+\mathrm{W})[\mathrm{kJ} / \mathrm{kg}]
\end{aligned}
$$

ここで, $\mathrm{C}$ 炭素, $\mathrm{H}$ 水素, $\mathrm{O}$ (diff.) 酸素, $\mathrm{S}$ 硫黄, $\mathrm{W}$ 全水分 (wt\%) とした。

これら 2 式によって算出した発熱量の分散度を検定した結

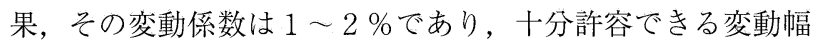
内にあることを確認した（Table 4)。

（3）チャー成分の保有エネルギー算出

チャー成分の保有エネルギー（\%) は，次式に示すように 試料の発熱量（式（1）を採用）に対する各温度で得られた チャー成分の保有エネルギーの比率で求めた。

・チャー成分の保有エネルギー（\%)

\begin{tabular}{|c|c|c|c|c|c|c|c|c|c|}
\hline \multirow{3}{*}{ Component } & \multirow{3}{*}{$\begin{array}{c}\text { Elemental } \\
\text { analysis }\end{array}$} & \multicolumn{2}{|c|}{$360^{\circ} \mathrm{C}$} & \multicolumn{2}{|c|}{$380^{\circ} \mathrm{C}$} & \multicolumn{2}{|c|}{$400^{\circ} \mathrm{C}$} & \multicolumn{2}{|c|}{$420^{\circ} \mathrm{C}$} \\
\hline & & \multicolumn{2}{|c|}{ Catalyst* } & \multicolumn{2}{|c|}{ Catalyst } & \multicolumn{2}{|c|}{ Catalyst } & \multicolumn{2}{|c|}{ Catalyst } \\
\hline & & no & yes & no & yes & no & yes & no & yes \\
\hline \multirow{5}{*}{ Tar } & $\mathrm{C}$ & 61.8 & 61.6 & 60.00 & 59.88 & 59.70 & 59.91 & 61.14 & 60.86 \\
\hline & $\mathrm{H}$ & 6.40 & 6.44 & 6.34 & 6.36 & 6.52 & 6.47 & 6.61 & 6.61 \\
\hline & $\mathrm{S}$ & 0.00 & 0.15 & 0.00 & 0.70 & 0.00 & 0.70 & 0.00 & 0.63 \\
\hline & $\mathrm{Cl}^{* *}$ & 2.24 & 2.22 & 1.43 & 1.62 & 1.56 & 1.55 & 1.46 & 1.38 \\
\hline & Sum & 70.44 & 70.41 & 67.77 & 68.56 & 67.78 & 68.63 & 69.21 & 69.48 \\
\hline \multirow{5}{*}{ Char } & $\mathrm{C}$ & 76.6 & 71.2 & 75.09 & 69.87 & 75.84 & 71.57 & 77.28 & 72.10 \\
\hline & $\mathrm{H}$ & 4.21 & 3.94 & 4.17 & 3.97 & 4.12 & 3.57 & 3.60 & 3.32 \\
\hline & $\mathrm{S}$ & 0.00 & 1.70 & 0.00 & 1.79 & 0.00 & 1.99 & 0.00 & 2.33 \\
\hline & $\mathrm{Cl}^{* * * *}$ & $0.38(0.27)$ & $0.36(0.21)$ & 0.57 & 0.57 & 0.56 & 0.82 & 0.58 & 0.81 \\
\hline & Sum & 81.19 & 77.20 & 79.83 & 76.20 & 80.52 & 77.95 & 81.46 & 78.56 \\
\hline
\end{tabular}

$=$ 試料を各温度で熱分解して得られるチャー成分にお

Table 3 Elemental analysis of tar / char component

(wt\% Dry Basis)

* Disposable iron sulfide (1.0 wt\%). ${ }^{* *}$ Total chlorine; Inorganic chlorine is not detected.

*** Total chlorine; Inorganic chlorine is designated in the parentheses.

Table 4 Calorific balance for char component formed by pyrolysis

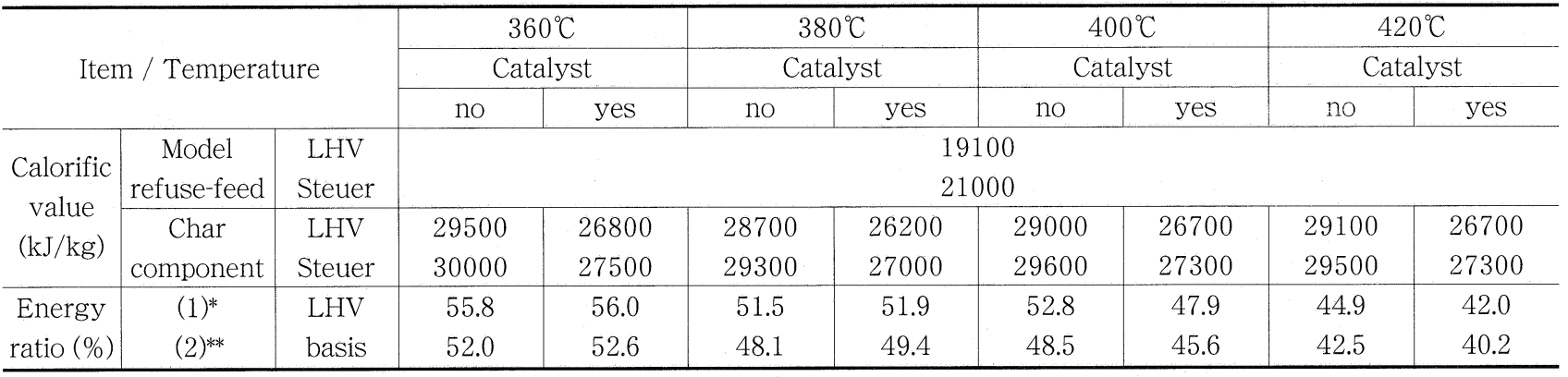

* Calorific balance based on heating value: ratio of heating value of char component to that of model refuse-feed, which could be transferred into second stage for total system.

** Calorific balance based on carbon content: ratio of amount of carbon in char component to that in model refuse-feed. 
ける $($ 発熱量 $\times$ 収率 $)\} \div$ (試料発熱量） $\times 100 \%$ なお，触媒が存在する場合のチャー成分収率はここでは，添 加触媒量を含んだものを使用した。

\subsection{2 考察}

（1）チャー成分の保有エネルギー

算出結果を Table 4 (1) と Fig. 6 に示す。これより，チャー 成分の保有エネルギーは温度上昇とともに減少した。これを 各温度領域で見ると，360～ $380^{\circ} \mathrm{C}$ では触媒有無による差異は

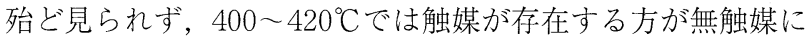
比べ低下した。これらのことは，次のように説明できる：ま ず360 380 $\mathrm{C}$ の低温度領域では，触媒が存在する場合は，触 媒を添加（1.0wt％）したためにチャ一成分中の灰分や金属な どの, 触媒由来の不燃物が増加し, その発熱量が無触媒の場 合に比べ見掛け上低下 (約 $2500 \sim 2700 \mathrm{~kJ} / \mathrm{kg}$ ) している (Table 4)。しかし, 見掛けのチャー成分収率も触媒の添加により増 大して抢り，これを補正すると，真のチャ一成分の保有エネ ルギーは無触媒のそれと殆ど差異が認められなかった。

これに対して，400〜 $420^{\circ} \mathrm{C}$ 高温度領域において，チャー 成分の保有エネルギーが触媒の存在によって低下した理由に ついて考察する。これを，チャー成分における発熱量と真の チャー成分收率に基づく質的，量的面から解析してみた。質 的面では，触媒有無間に扔ける発熱量の比率で見ると，低温 度領域 $\left(360 \sim 380^{\circ} \mathrm{C}\right)$ に扔けるそれと比較して殆ど変化して いない。一方，量的面では，真のチャー成分収率は触媒添加 に起因して大きく減少しており，このことが，高温度領域で 触媒の存在によって，チャー成分の保有エネルギーを無触媒 に比べ 8 \%程度低下させた主な原因であると考えられる。し かし，このように触媒が存在する場合においても，無触媒の 場合と同様に全測定温度領域においてチャー成分の保有工ネ ルギーとして，第二段燃焼炉に供給する目標值（40\%）が確 保されていることが確認できた。

（2）炭素比から求めたチャー成分の保有エネルギー 低温熱分解一高温燃焼から成る二段燃焼プロセスの熱収支

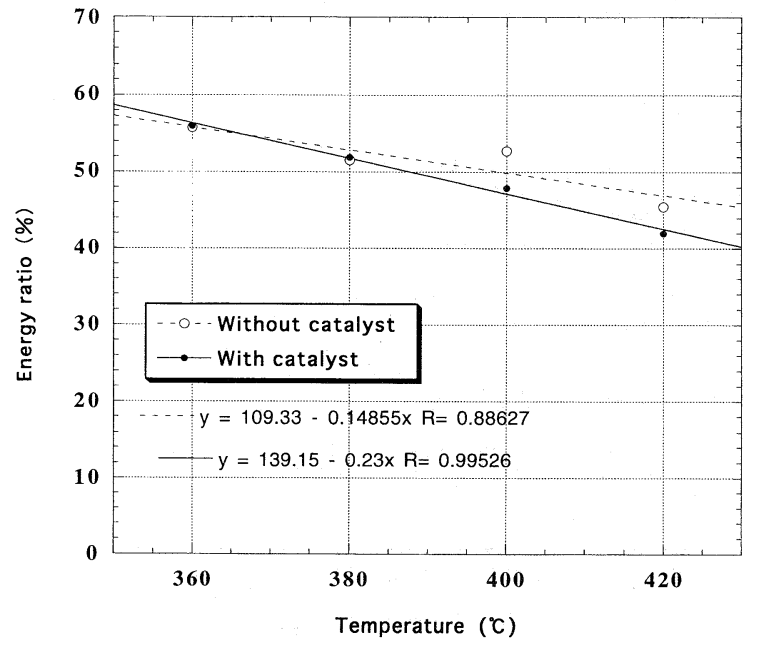

Fig. 6 Relationship between calorific balance* and pyrolysis temperature ( ${ }^{*}$ Based on heating balance)
を簡便に推定する手法について検討した。これは，上述のよ うにチャーとごみの発熱量を用いることなく, それらの炭素 含有量からチャーの保有エネルギー（）を求めようとする ものである。この保有エネルギーは，次式で定義した。

・炭素比からのチャー成分の保有エネルギー（\%)

$=$ (試料を各温度で熱分解して得られるチャー中の炭素

重量） $\div$ (試料中の炭素重量) $\times 100 \%$

ここで触媒が存在する場合のチャー成分収率は，チャー保有 エネルギー（\%）を求めるときと同様，添加触媒量を含んだ ものを使用した。

ここでの算出結果（Table 4 (2)）と，発熱量からのそれ (Table 4 (1)) とを比較したところ，両者の間で次の良好な関 係式が成立した。

・無触媒の場合：

$$
\begin{aligned}
& \text { チャー成分の保有エネルギー（\%) } \\
& \quad=1.1 \times \text { ×ャー成分の炭素比（\%) - } 1.0 （ \%)
\end{aligned}
$$

・触媒添加の場合 :

チャー成分の保有エネルギー（\%)

$=1.1 \times$ ×ャー成分の炭素比（\%) - 3.0（\%)

以上のことから，チャーの保有エネルギー（\%）は触媒存 在・非存在によらず，チャー成分の炭素比を用いることによ り，高度に推算することが可能であると結論した。

\section{4 熱分解における脱塩素反応}

Fig. 1に示すように，ごみ中の塩素は熱分解処理により熱分 解ガスとチャー成分に移行する。このプロセスでは, 高効率 発電を目指しているためボイラの高温高圧化が要求される。 しかし，都市ごみの燃焼ガス中に塩化水素や塩化物などの腐 食性ガスが存在すると, ボイラチューブの高温腐食が問題と なる ${ }^{25)}$ 。そこで，第一段熱分解炬で十分な脱塩素を達成する ことにより，第二段燃焼炉では腐食原因となる塩素の少ない クリーンなチャー成分を燃料とすることが可能となる。

本節では第一段熱分解炉における脱塩素反応について検討 し，併せて塩素の挙動，とくにどのような成分中に分配され るかについて確認した。

\subsection{1 試料の脱塩素反応}

まず，PVCを単独で熱分解し，2.5節で述べた定量法を用い て生成ガス中の $\mathrm{HCl}$ と $\mathrm{Cl}_{2}$ を分析した。この結果, PVCの熱分 解条件 $\left(\mathrm{O}_{2} 5.7 \mathrm{vol} \%, \mathrm{~N}_{2} ; 360 \sim 420^{\circ} \mathrm{C}\right)$ によらずPVCに含有 する塩素は $\mathrm{HCl}$ として定量的に $100 \%$ 気相中に放出されてい ることを確認し，この結果は他の文献のそれとも一致してい る26)。次いで，試料 (木材チップ+PVC) を用いて触媒 (1.0wt \%) の添加有無における熱分解実験 $\left(\mathrm{O}_{2} 5.7 \mathrm{vol} \% ， 360 ４ 20\right.$ $\left.{ }^{\circ} \mathrm{C}\right)$ を行い, 試料における PVC中塩素の, 熱分解生成物への 分配を明らかにした（Table 5)。

Table 5 より, 各成分への Cl分配率（\%) は，高い順から低 い順に, 発生 $\mathrm{HCl} 72.5 \sim 84.5 \%$, 夕ール成分 $4.3 \sim 7.1 \%$, チャー 成分 1.6 ～3.2\%であった。また，各成分の塩素分配率の合計

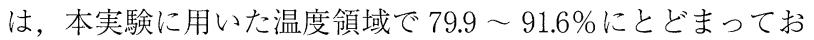


Table $5 \mathrm{Cl}$ distribution to tar and char component besides $\mathrm{HCl}$

\begin{tabular}{c|c|c|c|c|c|c|c|c}
\hline \multirow{3}{*}{ Component } & \multicolumn{2}{|c|}{$360^{\circ} \mathrm{C}$} & \multicolumn{2}{c|}{$380^{\circ} \mathrm{C}$} & \multicolumn{2}{c|}{$400^{\circ} \mathrm{C}$} & \multicolumn{2}{c}{$420^{\circ} \mathrm{C}$} \\
\cline { 2 - 10 } & \multicolumn{2}{|c|}{ Catalyst } & \multicolumn{2}{c|}{ Catalyst } & \multicolumn{2}{c}{ Catalyst } & \multicolumn{2}{c}{ Catalyst } \\
\cline { 2 - 10 } & no & yes & no & yes & no & yes & no & yes \\
\hline Tar* & 7.1 & 6.3 & 4.3 & 4.9 & 4.7 & 4.3 & 4.7 & 4.5 \\
\hline Char** & 1.7 & 1.6 & 2.5 & 2.5 & 2.4 & 3.2 & 2.1 & 2.7 \\
\hline HCl evolved & 78.5 & 75.0 & 74.8 & 72.5 & 84.5 & 77.4 & 77.1 & 75.6 \\
\hline Total Cl captured & 87.3 & 82.9 & 81.6 & 79.9 & 91.6 & 84.9 & 83.9 & 82.8 \\
\hline
\end{tabular}

* Ratio of $\mathrm{Cl}$ involved in each component to that in PVC of model refuse-feed.

** Calculated from material balance and elemental analysis.

り，PVC単独の熱分解実験結果とは大きく異なった。塩素分 配率の合計が低下した理由として，熱分解で得られた液状生 成物から THF を留去する過程（2.5 節の操作）で低沸点成分 が散逸しているが，この低沸点成分中に塩素の一部が分配さ れている可能性が存在する。実際に単離されたタール成分に $4.3 \sim 7.1 \%$ の塩素が分配されている。

以上の結果より，チャーへの塩素分配率は $1.6 \sim 3.2 \%$ であ $\eta$ ，第二段燃焼炉の材質に対する負荷を低減させるためのプ ロセス目標值である第一段熱分解炉での脱塩素率 $95 \%$ は, 本 実験に用いたすべての温度領域で達成されていることがわか

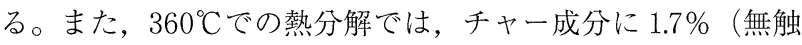
媒）抢よび $1.6 \%$ (触媒有) のPVC由来の塩素が分配されてい るが(Table 5), その中で全塩素に対して有機塩素として存在 している割合が，それぞれ $29 \%$ および $42 \% に$ 達していること が注目される。

\subsection{2 炭化水素骨格構造の違いによる脱塩素反応}

上述の木材試料との有機塩素化の違いを比較検討するため, PVCの共存試料種として, 次の代表的な炭化水素骨格構造を 有する可燃物質（6 種）を使用した。検討した共存試料種は, 直鎖および分岐状鎖状構造を持つポリエチレン（HDPE， LDPE)，側鎖に芳香環を持つポリスチレン(GPPS, HIPS)，お よび木材の構成成分であるセルロース，リグニン (Fig. 2) で ある。

試料（試料種+ PVC）を熱分解 $\left(\mathrm{O}_{2} 5.7 \mathrm{vol} \%, 360^{\circ} \mathrm{C}\right)$ した ときの, 気相中 HClへの塩素分配率はLDPEやHDPE, GPPS, HIPSでは100\%であり，セルロース，リグニンではそれぞれ， 83.6\%，63.1\%であった。この結果は, LDPEやHDPE, GPPS, HIPSではタールおよびチャー中に炭素一塩素結合を伴った塩 素分配が生じていないが，セルロースおよびリグニンではそ れが進行している可能性があることを示唆している。LDPE等 の炭化水素化合物で有機塩素化が見られなかった理由として は, PVCとこれらの炭化水素の熱分解特性が異なるためと考 えられる。すなわち, PVCでは約 $300^{\circ} \mathrm{C}$ 以下で $\mathrm{HCl}$ ガスが発 生するのに対し, HDPE, LDPEでは $400 \sim 450^{\circ} \mathrm{C}$, GPPS, HIPS では $360 \sim 420^{\circ} \mathrm{C}$ で熱分解フラグメントが生成することから 26a)，これらの炭化水素がまだ安定である中に，PVCの脱塩化 水素反応が終了してしまうためと推察される。これに対して, セルロースやリグニンでは, その熱分解フラグメントの生成 温度がPVCの脱塩化水素反応のそれと近接しているため, 両
成分が熱分解過程で接触し, 有機塩素化が進行したものと思 われる。

次に, 有機塩素化の進行が示唆されたセルロースとリグニ

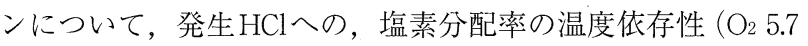
$\left.\mathrm{vol} \% ， 360 \sim 420^{\circ} \mathrm{C}\right)$ を検討した。この結果を木材試料の場合 と比較して Fig. 7 に示す。これを見ると，セルロース，リグ ニンとも温度依存性は殆どなかった。しかし, 発生 $\mathrm{HCl} へ$ へ 塩素分配率については，木材では $74.8 ８ 4.5 \%$ （全実験值の 平均值 78.7\%) であったのに対し，セルロースでは 81.5 84.2 (83.3\%), リグニンでは $58.1 〜 67.7 \%$ (62.3\%) とリグニンに おいて最も気相への塩素分配率が低かった。また，木材での 気相への塩素分配率は, 本実験で用いた木材チップ中のリグ ニンとセルロースの構成比 ${ }^{11 \mathrm{~b})}(30 \%: 70 \%)$ の加重平均值に 相当している。

さらに，セルロース抽よ゙リグニンを熱分解 $\left(\mathrm{O}_{2} 5.7 \mathrm{vol} \%\right.$, $360 \sim 420^{\circ} \mathrm{C}$ ) したとき得られたタール成分の芳香族性を確認 した。ここでは, タール成分をべンゼン抽出し，これについ て ${ }^{1} \mathrm{H}-\mathrm{NMR}$ 構造解析を行い, 全水素数に占める芳香族性水素 の割合を示すHar/Htotalを求めた(Table 6)。この結果は, リ グニン由来のベンゼン抽出成分はセルロース由来のそれと比 較して芳香族性が1.5〜 1.8倍高くなっており, Fig. 2に示した 両成分の単位構造中の化学構造を反映したものとなっている。

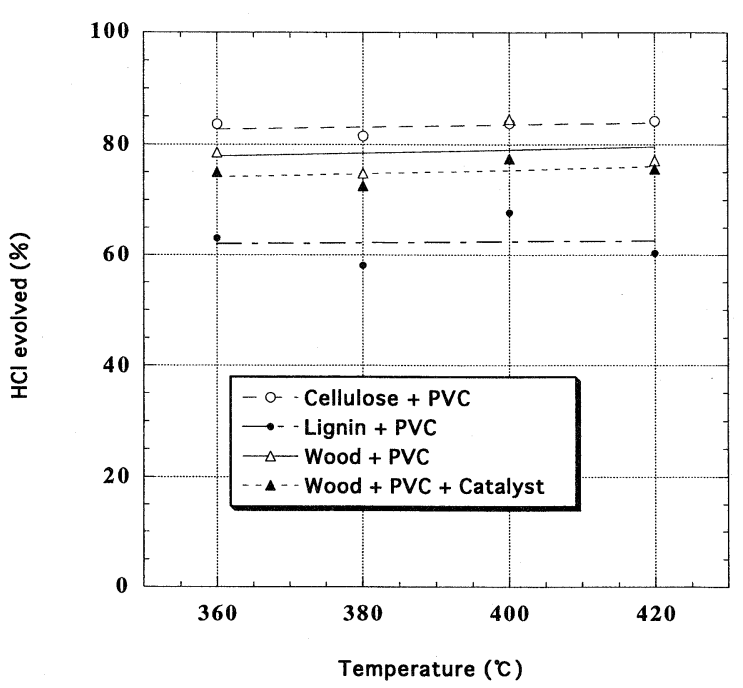

Fig. 7 Relationship between $\mathrm{HCl}$ evolved and pyrolysis temperature 
Table $6 \mathrm{Har}_{\mathrm{ar}} / \mathrm{H}_{\mathrm{total}}{ }^{*}$ in benzene extract from tar component ${ }^{* *}$

\begin{tabular}{c|c|c}
\hline \multirow{2}{*}{ Sample } & \multicolumn{2}{|c}{$\mathrm{Har} / \mathrm{H}$ total } \\
\cline { 2 - 3 } & $360^{\circ} \mathrm{C}$ & $420^{\circ} \mathrm{C}$ \\
\hline Cellulose + PVC & 0.136 & 0.111 \\
Lignin + PVC & 0.205 & 0.196 \\
\hline
\end{tabular}

* Ratio of aromatic hydrogens to total hydrogens: ${ }^{1} \mathrm{H}-\mathrm{NMR}(270$ $\mathrm{MHz}, \delta=6-9 \mathrm{ppm}), \mathrm{CDCl}_{3}$ solvent.

** Formed by pyrolysis of cellulose and lignin without catalyst.

\subsection{3 有機塩素化成分の特定とその Cl 分配}

本節では，どのような化学構造に炭素一塩素結合が生成し ているかを特定し，それら成分への塩素分配率を定量化する ことにより，有機塩素化機構を検討した。併せて触媒添加有 無による塩素化反応に及ぼす影響を確認した。

生成タールから分離された各成分へのCl分配：木材との熱 分解では，上述したように気相以外にチャーや夕ール成分へ 塩素が分配されている。しかし，チャー成分への有機塩素の 分配は $360^{\circ} \mathrm{C}$ では $0.5 \sim 0.7 \%$ と僅かであるため (3.4.1節)，こ こではタール成分（無機 $\mathrm{Cl}$ の検出は認められなかった）を酸 性成分と非酸性成分に分離し，塩素分配挙動に着目して検討 した。タール成分からチャー成分に至る化学構造には連続性 が存在することから，チャー中の炭素一塩素結合の生成にお いても夕ール成分の解析結果とある程度類似性があると思わ れる。

試料（木材チップ+ PVC）の熱分解 $\left(\mathrm{O}_{2} 5.7 \mathrm{vol} \%, 360^{\circ} \mathrm{C}\right.$, 触媒添加有無）で生成したタール成分を使用し，陰イオン交 換樹脂を用いて分離した 2 成分(酸性成分および非酸性成分) への塩素分配率（\%）をFig. 8 に示す。併せて，図中には各 分離過程で得られた成分の収率の值も記載した。ここで，各 分離成分の塩素分配率と収率は，熱分解試料の重量とその $\mathrm{Cl}$ 含有量を，それぞれ 100 としたときの比率（\%）である。ま た，ベンゼン溶出成分は樹脂と相互作用を持たずにそのまま 溶出した成分 (非酸性成分) であり, $\mathrm{CO}_{2}$ 飽和メ夕ノール溶出

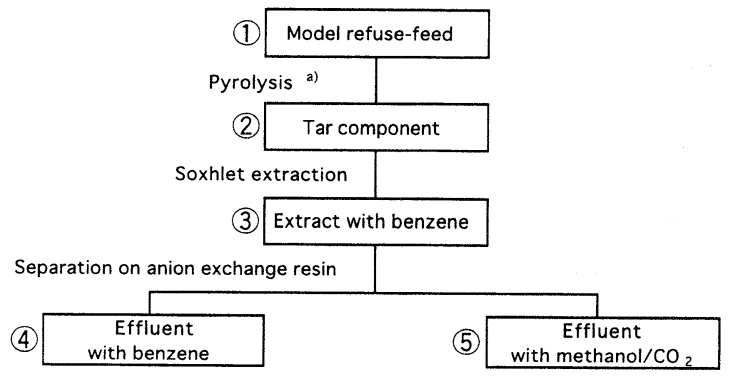

\begin{tabular}{c|c|c|c|c}
\hline \multirow{2}{*}{ Sream No. } & \multicolumn{2}{|c|}{$\begin{array}{c}\text { Yields } \\
(\%)\end{array}$} & \multicolumn{2}{c}{$\begin{array}{c}\text { Cl distribution } \\
\text { b) } \\
(\%)\end{array}$} \\
\cline { 2 - 5 } & \multicolumn{2}{|c|}{ Catalyst } & \multicolumn{2}{c}{ Catalyst } \\
\cline { 2 - 5 } & no & yes & no & yes \\
\hline 1 & 100 & 100 & 100 & 100 \\
2 & 25.3 & 23.2 & 7.1 & 6.3 \\
3 & 13.6 & 5.1 & 3.5 & 1.1 \\
4 & 6.5 & 2.2 & 0.9 & 0.4 \\
5 & 7.1 & 3.0 & 2.6 & 0.7 \\
\hline a) Pyrolysis conditions: $360^{\circ} \mathrm{C} ; \mathrm{O}_{2} 5.7$ vol\%; $1.0 \mathrm{wt} \%$ of disposal iron \\
sulfide catalyst. b) Throughout stream.
\end{tabular}

Fig. $8 \mathrm{Cl}$ distribution to fractions from tar component formed by pyrolysis of model refuse-feed
成分は，樹脂と相互作用を持った成分を脱着させて溶出した 炭酸より弱い酸性を有する成分（酸性成分）である。 $360^{\circ} \mathrm{C}$, 無触媒での熱分解タール中には試料中に含まれる塩素の $7.1 \%$ が分配されていることは上述したが，ベンゼン可溶なタール 成分への分配率は $3.5 \%$ あ゙あた。その中で酸性成分/非酸性 成分に含まれる塩素量は $74: 26$ あり, 両成分の収率比 $(52$ : 48）考慮すれば，炭素一塩素結合の生成は，酸性成分に，よ り濃縮されていることがわかる。

そこで，この炭素一塩素結合は分離成分中の，とくに酸性 成分の中にどのような化学構造で存在しているかを検討した。 まず希薄溶液 IR 法により, 遊離のフェノール性 $\mathrm{OH}$ 基の伸縮 振動による特性吸収の帰属を検討した ${ }^{20)}$ 。次いで, ${ }^{13} \mathrm{C}-\mathrm{NMR}$ (脂肪族/芳香族炭素の存在比率を決定）と, IR 抢よび元素分 析を用いた解析により, 芳香環 1 個あたりの塩素とフェノー ル性 $\mathrm{OH}$ 基の置換数を求めた。この結果，IR 測定では，3550 $\mathrm{cm}^{-1}$ の吸収特性が酸性成分にのみ特徵的に出現し(Fig. 9), 樹 脂による分離によってフェノール類が酸性成分として濃縮さ れたことが確認できる。また， $\mathrm{CO}_{2}$ 飽和メタノールで樹脂の吸 着成分を溶出させた後, ギ酸/ THF 溶液での溶出操作におい ては有意量の成分は回収されなかった。クレゾール類・キシ レノール類の混合物の遊離フェノール性 $\mathrm{OH}$ 基の伸縮振動は $3590 \mathrm{~cm}^{-1}$ に特性吸収を有することが確認されており 20) 27), $40 \mathrm{~cm}^{-1}$ の低波数シフトはフェノール骨格に塩素が置換されて いることを示唆している (o-クロロフェノールの v $\mathrm{OH}_{\mathrm{H}}=3540$ $\left.\mathrm{cm}^{-1}\right)$ 。酸性成分中に存在する塩素の全てが芳香環に置換され ていると仮定した場合, 芳香環 1 個あたりの塩素置換数は無 触媒熱分解の場合 0.22 個と計算され (Table 7), 芳香環 1 個 あたりのフェノール性 $\mathrm{OH}$ 基数の約 1.4 倍に相当する（3550 $\mathrm{cm}^{-1}$ に現れる特性吸収の平均分子吸光係数の值を, $O^{-}$クロロ フェノールのそれ $\left(\varepsilon=167 \mathrm{M}^{-1} \mathrm{~cm}^{-1}\right)$ と仮定した)。したがっ て，木材チップ/PVC系熱分解において，タール成分中に生 成する炭素一塩素結合は, リグニン由来のフェノール性フェ ニルプロパン単位構造を保持した熱分解生成物の芳香環部位 (OH 基のオルト位あるいはパラ位) に核置換された構造が優 先的に生成したと考えられる。

触媒添加有無が塩素化反応に及ぼす影響：次に, 触媒添加 有無による各分離成分への塩素分配挙動と, タール成分の溶 媒溶解性に及ぼす影響について考察した。まずFig. 8 の Cl 分 配率を見ると，無触媒時に対する触媒存在下でのCl低減率は，

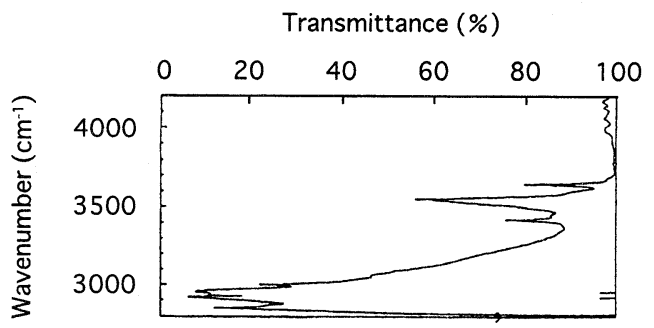

Fig. 9 IR spectrum* of acidic fraction from tar component formed by pyrolysis of model refuse-feed in the absence of catalyst ( ${ }^{*}$ Recorded on a JASCO FT/ IR-5300 spectrometer (optical pass distance, $2 \mathrm{~cm}$; $\mathrm{KBr}$ liquid cell)) 
Table 7 Substituted numbers of $\mathrm{Cl}$ and $\mathrm{OH}$ groups per a unit aromatic ring involved in the two separated fractions from tar component*

\begin{tabular}{c|c|c|c}
\hline \multirow{2}{*}{$\begin{array}{c}\text { Separated } \\
\text { fraction** }\end{array}$} & \multirow{2}{*}{ Catalyst*** } & \multicolumn{2}{|c}{$\begin{array}{c}\text { Substituted number } \\
\text { per an aromatic ring**** }\end{array}$} \\
\cline { 3 - 4 } & & $\mathrm{Cl}$ & $\begin{array}{c}\text { Phenolic } \\
\text { OH group }\end{array}$ \\
\cline { 3 - 4 } & & 0.22 & 0.16 \\
Acidic & no & 0.10 & 0.14 \\
fraction & yes & 0.10 & 0 \\
\hline Acid-free & no & 0.13 & 0 \\
fraction & yes & \\
\hline
\end{tabular}

* Formed by pyrolysis of model-feed under $\mathrm{O}_{2} 5.7 \mathrm{vol} \%$ stream at $360^{\circ} \mathrm{C}$.

** Tar components are extracted with benzene and then separated by anion exchange resin (IRA-904).

*** Disposable iron sulfide (1.0 wt\%).

**** Calculated by means of carbon-13 NMR and IR spectra as well as elemental analysis.

****** Average molar absorption coefficient assumed: $\varepsilon=167(\mathrm{M} \cdot \mathrm{cm})^{-1}$

タール成分ではさほど大きな差異が見られなかったものの (低減率：11\% in Stream No. 2)， ベンゼン抽出成分と酸性成 分ではいずれも顕著に低減した（69\% in Stream No. 3 ; 73\% in Stream No. 5)。すなわち触媒添加により，塩素置換された フェノール性骨格構造が大きく減少したことが特徵的である。 さらにタール成分の溶媒溶解性を見ると, ベンゼン溶解性で は53.7\% (無触媒) から $22.0 \%$ (触媒有) に大きく減少してい る (Stream No. $2 \rightarrow$ No. 3 in Yields)。これに対し, ベンゼン 抽出成分の二硫化炭素溶解性ではむしろ $63.3 \%$ (無触媒) か ら $88.5 \%$ (触媒有) に増大している。このことは, 触媒存在下 における熱分解フラグメントの不均化が加速され, 重縮合に よる重質化と接触分解の寄与を伴う軽質化が同時に進行した ためと推定できる。この中でフェノール性フェニルプロパン 構造単位を有する比較的分子量の小さい成分が優先的に分解 され, 酸性成分中の炭素一塩素結合の生成を大きく削減でき たものと考えられる。触媒存在下に扔いても残存している酸 性成分中の塩素が芳香環 1 個あたりに存在する量は, 無触媒 に比べて約 20\%減少している (Table 7)。

なお，本熱分解実験は低酸素濃度雲囲気下で行われている ため, 接触分解時に酸化反応が促進される可能性がある。そ こで，この可能性を知るため，タール成分中に存在する酸素 含有量に着目して考察した。Table 3 より，試料（木材チップ $+\mathrm{PVC}$ ) の接触分解で生成したタール中の酸素 (diff.) は, 用 いた全温度領域で 29.6 ～31.4wt\% であり，分解温度によらず 殆ど変化していない。また，夕ール成分のIRスペクトル解析 からも含酸素構造の発現はみられず，これらのことから，本 反応における触媒効果として炭素質の酸化反応の促進に及ぼ す寄与は小さいものと考えられる。

有機塩素化機構：これまで得られた知見をふまえて，木材 試料の熱分解過程での有機塩素化機構について考察した。木 材中のリグニンに含まれる骨格物質である芳香環への有機塩 素化反応機構として，(1)遊離塩素による芳香族求電子置換反 応，(2)遊離塩素による芳香族ラジカル置換反応，および(3)塩

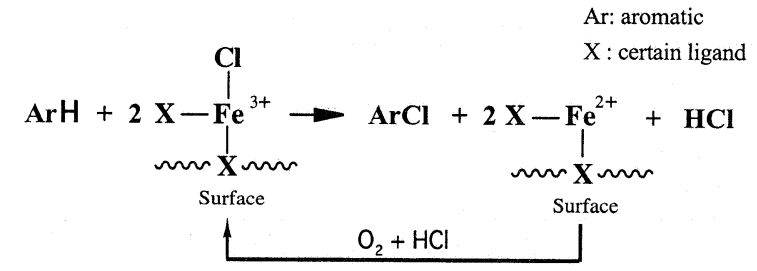

II

Scheme 1 Proposed mechanism for chlorination of skeletal substance contained in lignin

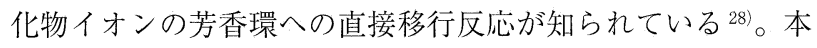
研究で得られた塩素化機構に係わる知見として, 熱分解過程 で生成する気相中には, Deacon 反応 $\left(2 \mathrm{HCl}+1 / 2 \mathrm{O}_{2} \rightarrow \mathrm{H}_{2} \mathrm{O}+\right.$ $\left.\mathrm{Cl}_{2}\right)$ による遊離塩素の生成は確認されなかったこと(3.1節)， および塩素は水酸基により活性化された芳香環部位に優先的 に導入されたこと（本節）を考慮すると, 本研究における有 機塩素化機構は, (3)の塩化物イオンのオキシクロリネーショ ン型反応による芳香環への求電子的直接移行反応である可能 性が最も高い。他の多くの実験的研究でも, 有機塩素化の経 路としてDeacon反応の果たす役割が小さいことが報告されて いる ${ }^{29)}$ 。オキシクロリネーション反応は, ルイス酸性の大き な金属塩化物, とくに塩化鉄 (III) の存在によって促進される ことはよく知られており ${ }^{30)} 31$, , 灰分中の金属塩による触媒効 果によって塩素化が加速されると推定できる。有機塩素化は Scheme 1に示すような反応機構が提案されており ${ }^{30)}$, 鉄一塩 素錯体の生成が塩化物イオンの芳香環への直接移行反応にお ける触媒活性種であると推定している。ここでは, 鉄イオン は 3 価から 2 価に還元され錯体 II となり, 錯体 II は酸素と塩 化水素の存在により再酸化されて錯体Iに戻る ( 2 電子レドッ クスサイクル)。Scheme 1に従えば，本実験研究で得られた次 の知見はよく説明できる:すなわち, (1)触媒が存在すると, 触 媒活性の発現による物質収支および熱収支への影響が見られ たこと (3.2.2 および3.3.2節)，また(2)気相への塩素分配率は触 媒が存在すると，無触媒に比べて $2.3 〜 7.1 \%$ 低下したものの, 有機塩素化反応自体は, むしろ促進されていると考えられる こと (Fig. 7), さらに(3)チャー中の $\mathrm{Cl}$ 含有量 $(0.36 \sim 0.82 \mathrm{wt}$ \%) が分解温度上昇に伴い増大し，とくに高温度領域では触 媒添加の方が無添加に比べ 1.4 倍多く存在しており, $\mathrm{Cl}$ が触 媒中のFe分と錯体を形成し固定されていることを示唆してい ること (Table 3)である。このように, 触媒存在下では, 夕一 ル成分での有機塩素化は促進されるものの, 接触分解によっ てフェノール性フェニルプロパン誘導体を持つ比較的低分子 量の成分がより選択的かつ優先的な分解を受けるため, ダイ オキシン類生成で大きな役割を果たすと考えられるクロロ フェノール類 (前駆体) の生成制御が顕著に達成されたと結 論した。

\section{5 第一段低温熱分解過程におけるプロセス条件の検討}

以上の結果をふまえて流動床二段廃棄物燃焼炉のトータル システムの中で，第一段熱分解炉に㧍けるプロセス条件を検 
討した。

第一段熱分解炉でのプロセス目標值として，まず次の 3 点 が前提となる：(1)チャー成分の脱塩素率を $95 \%$ 以上とする, (2)試料が持つ全熱量の $40 \%$ 以上をチャー成分に分配する，(3) 触媒添加によるダイオキシン類前駆体の削減効果が認められ る。これに対して，本実験研究でこれまで得られた結果はそ のすべてを満足している（3.4.1，3.3.2 拉よび 3.4 .3 節）。また， 添加触媒量の効果については，ごく少量の添加量 (0.094wt\%, 金属含有量）によってもダイオキシン類前駆体の生成が著し く低減できることが明らかにされている ${ }^{14)} 。 一$ 方，触媒の添 加により，触媒コストが増加し，また，第一段熱分解炬で $\mathrm{H}_{2} \mathrm{~S}$ が発生し後段の燃焼過程で $\mathrm{SO}$ x となり環境負荷が増大する。 しかし，触媒は使い捨てであるため安価である上に，その添 加量や循環に上る劣化等の補充は極めて少量にとどめること ができると推定され，さらに本システムは後流に排ガス処理 装置を備えており，ここでの $\mathrm{SO}_{\mathrm{x}}$ 除去が可能であると思われ る。

本研究での熱分解実験は流通式反応管（固定床反応器）を 用いているのに対し，想定した実基での反応装置は流動床で ある。そこで，この条件の違いに対する考察を次のと㧍り試 みた。考察は，固定層と流動層状態の大きな相違（層内粒子 の混合・粉砕の有無, 層の熱伝達率の大小) を考慮し, 本研 究と関連した文献を参考にしながら行った。劉ら ${ }^{322}$ は，管状 反応管を用いて，流動層とスト一カの炉内条件を想定し，Ca を含む RDF（固形化燃料）ペレットの熱分解・低酸素燃焼実 験を行っている。ここでは, 流動層とストーカの炉内条件の 違いを，それぞれ急速昇温 $\left(4.2^{\circ} \mathrm{C} / \mathrm{s}\right)$ および低速昇温 $\left(0.2^{\circ} \mathrm{C} /\right.$ s)でモデル化し, 各条件での昇温速度がRDF粒子内部での温 度分布と塩化水素生成挙動に与える影響について検討してい る。この結果，チャー中への塩素捕捉率は，流動床条件の方 （約 61\%）がストーカのそれ（約 43\%）よりも高くなること を明らかにした。その差異の理由として，低速昇温条件下（ス トーカ炉) ではRDF 粒子内部の温度勾配が小さく，これに対 して，急速昇温（流動床）では RDF 粒子内部の温度勾配が大 きくなり，比較的内部温度が低い熱分解初期段階で放出され た塩素分が内部のCaと接触して吸収されるためと報告してい る。一方，本熱分解実験では，破砕された小粒径試料（1～ $2 \mathrm{~mm})$ はかなり大きな急速加熱 $\left(0.7 \sim 0.8^{\circ} \mathrm{C} / \mathrm{s}\right)$ で熱分解さ れていること方，粒子内部の温度分布はほほ均一と考えら れ，したがって，本実験での $\mathrm{HCl}$ 生成挙動は，上述文献の流 動床条件下でのそ机に近いと推定される。なお，チャー中へ の塩素捕捉率が低かった理由は, 試料中にCaが存在しなかっ たためであると考兄られる（チャー中への $\mathrm{Cl}$ 分配率約 $2 \%$; Table 5)。次に, V. Cozzaniら ${ }^{16)}$ は, 固定床反応器を用いた実 験によって, 反応速度論的観点から微粉砕RDFの熱分解過程 の反応速度に関しモデル解析を行っている。この中で，他の 文献に㧍ける流動床のそれと比較検討した結果，両者の熱分 解速度は, 反応システムが異なっても良好に一致したとして いる。以上のことを合わせて考えると，本実験研究で得られ たデー夕は，必ずしも上述した文献の内容と一致するもので
はないが，基礎的反応条件（化学平衡，反応速度等）におい て全体として流動床条件と相関があり，想定した流動床を開 発する際にある程度の指針になるものと判断される。

\section{4. 結 論}

都市ごみのモデル試料を用いて，流動床二段廃棄物燃焼炉 の構成部分である第一段熱分解炬について要素研究を行った。 この結果，次の知見が得られた。

(1) 熱分解過程で生成するチャ一成分の保有エネルギーは, 触媒の有無によらず $420^{\circ} \mathrm{C}$ 以下の温度領域に扔いては, プロセス目標值である $40 \%$ 以上の值を保持した。

(2) 試料の熱分解で $50 \% \mathrm{FeS}$ 触媒が存在すると, 高温度領域 において触媒活性の発現により，物質収支抢よび熱収支 に対する影響が8〜 10\%程度低下し，これに伴って生 成タールの一部軽質化がみられた。

(3) チャー成分中の塩素分配率は, 目標値 $5 \%$ 以下に対して 1.6〜 3.2\%にとどまり，クリーンなチャー成分を第二段 燃焼炉に供給できることがわかった。

(4) 試料の熱分解で触媒を添加すると, ダイオキシン類前駆 体の生成制御が可能であることが示された。

\section{文 献：References}

1) 環境省編，循環型社会白書 (平成 14 年版) (ぎょうせい), p. 110 (2002) : Ministry of the Environmnt, White Paper on the Recycling-based Society (Gyosei), p. 110(2002)

2）ダイオキシン対策関係閣僚会議, ダイオキシン対策推進基 本指針，環境庁ホームページ，http://www.eic.or.jp/eanet/ (1999): The Ministerial Council on Dioxin Policy, Basic Guidelines of Japan for the Promotion of Measures against Dioxins (Ministry of the Environment), http://www.env. go.jp (1999)

3）貝原裕二，新型熱分解・ガス化溶融システムの開発事例, 廃棄物の熱分解・ガス化灰溶融システムの開発動向（エ ヌ・ティー・エス), p. 129(1998):Kaihara, Y., Development of MSW Gasification system(NTS, Inc.), p. 129(1998)

4）森滋勝, 近藤元博, 板谷義紀, 化学工学論文集, 29(4), 453 (2003) : Mori, S., Kondo, M., and Itaya, Y., Kagaku Kogaku Ronbunsyu, 29 (4), 453(2003)

5）寺澤良則他，三菱重工技報，38(1), 16(2001.1): Terasawa， Y., et al., Mitsubishi Juko Giho, 38(1), 16(2001. 1)

6）茅陽一ら編，エネルギーの百科事典 (丸善), p. 280(2001): Kaya, Y., et al., Encyclopedia of Energy Science(Maruzen), p. 280 (2001)

7) Avenell, C. S., Sainz-Diaz, C. I., and Griffiths, A. J., Fuel, 75, 1167(1996)

8) Weber, R., and Sakurai, T., Chemosphere, 45, 1111(2001)

9) Li, A. M., Li, X. D., Li, S. Q., Ren, Y., Shang, N., Chi, Y., Yan, J. H. and Cen, K. F., Energy, 24, 209 (1999)

10) Schaefer, W. D., Environ. Sci. Technol., 9 (2), 98(1975)

11）a）中野準三編，リグニンの化学(増補改訂版) (ユニ出版), 
p. 13, p. 131 (1990) : Nakano, J., lignin no Kagaku(Uni Publishers), p. 13, p. 131(1990)； b) 原口隆英ら，木材の 化学 (文永堂出版), p. 4, p. 110 (1993): Haraguchi, T., Mokuzai no Kagaku(Buneido Publishing), p. 4, p.110(1993)

12）a）セルロース学会編，セルロースの事典（朝倉書店）, p. 5(2000): The Cellulose Society of Japan, Encyclopedia of Cellulose (Asakura Publishing), p. 5(2000)；b) 平岡正勝 編, 廃裹物処理とダイオキシン対策(環境公害新聞社), p. 8(1993): Hiraoka, M., Haikibutsu Shori to Dioxin Taisaku (Kankyoshimbunsha), p. 8(1993)；c) 清水剛夫監訳代表, ダイオキシン (エヌ・ティー・エス)，p.267(1999)： Ballschmiter, K., and Bacher, R., Dioxine (VCH Verlagsgesellschaft mbH), p. 267 (1999)

13）神谷佳男, 真田雄三, 富田彰, 石炭と重質油(講談社), p. 99 (1979) : Kamiya, Y., Sanada, Y., and Tomita, A., Sekitan to Jushitsuyu(Kodansha), p. 99(1979)

14）a）原孝夫，廃菓物の熱分解過程における有機化合物の挙 動について(ダイオキシン類前駆体生成制御に関する基礎 研究) (三菱重工業株式会社材料·化学研究会資料)，(1997. 11) : Hara, T., Report from the committee on the Behavior of Organic Compounds During the Low-Temperature Pyrolysis of MSW (Mitsubishi Heavy Industries), (1997.11); b) Yamamoto, H., Ikeda, T., Taguchi, T., and Hara, T., Reduction of Dioxins-Precursor Formed During Pyrolysis Process in the Two-Stage Fluidized-Bed Incinerator, $J$. of the Japan Inst. of Energy, manuscript in preparation

15）廃棄物学会編，廃棄物ハンドブック (コンパクト版) (オー ム社)，p. 163(1997):Japan Society of Waste Management Experts, Haikibutsu Handbook (Ohmsha), p. 163(1997)

16) Cozzani, V., Nicolella, C., Petarca, L., Rovatti, M., and Tognotti, L., Ind. Eng. Chem. Res., 34, 2006 (1995)

17) a) Ruokojärvi, P. H, Halonen, I. A, Tuppurainen, K. A, Tarhanen, J., and Ruuskanen, J., Environ. Sci. Technol., 32, 3099 (1998) ; b) Fangmark, I., Stromberg, B., Berge, N., and Rappe, C., Environ. Sci. Technol., 28 (4), 624(1994)

18) Born, J. G. P., Louw, R., and Mulder, P., Chemosphere, 26 (12), 2087 (1993)

19) Jewell, D. M., Weber, J. H., Bunger, J. W., Plancher, H., and Latham, D. R., Anal. Chem., 44, 1391(1972)
20) Young, L. -J. S., Hara, T., and Li, N. C., Fuel, 63 (6), 816(1984)

21) Heek, K. H., Strobel, B. O., and Wanzl, W., Fuel, 73 (7), 1135 (1994)

22）雨宮登三，石油化学(産業図書), p. 121(1961):Amemiya, T., Sekiyu Kagaku (Sangyotosho), p. 121(1961)

23） a）原孝夫，炭化反応の化学的解明一副産生成物の生成機 構とタール塩基の改質，石炭の炭化反応機構(日本鉄鋼協 会), p. 119(1989)：Hara, T., Chemical Approach for Understanding of Carbonization Reaction of Coal (The Iron and Steel Institute of Japan), p. 119(1989) ; b) 原孝夫，コー クス化機構の基礎研究一乾留時生成物分析による解明，石 炭のコークス化特性部会報告書（日本鉄鋼協会）, p. 59 (1985) : Hara, T., Report from Comittee on the Basic Research on the Coking Mechanism of Coal (The Iron and Steel Institute of Japan), p. 59(1985)

24）日本熱エネルギー技術協会編，熱管理便覧(改訂三版) (丸 善), p. 303(1972) : The Energy Conservation Center, Japan; Netsu Kanri Binran(Maruzen), p. 303(1972)

25）日本ボイラー協会編，新版ボイラー便覧（丸善)，p. 294 (1997): Japan Boiler Association, Boiler Handbook (Maruzen), p. 294(1997)

26）a）来栖慎吾他，三菱重工技報，10(5)，787(1973.9)： Kurusu, S., et al., Mitsubishi Juko Giho, 10 (5), 787 (1973. 9) ; b) Wirts, M., Lorenz, W., and Bahadir, M., Chemosphere, 37, 1489(1998)

27) Hara, T., PETROTECH, 4 (10), 925(1981)

28) Addink, R., and Olie, K., Environ. Sci. Technol., 29 (6), 1425 (1995)

29) Addink, R., and Altwicker, E. R., Organohalogen Compounds, 27, 1 (1996)

30) Hoffman, R. V., Eiceman, G. A., Long, Y. -T., Collins, M. C., and Lu, M. -Q., Environ. Sci. Technol., 24(11), 1635(1990)

31) a) Nestrick, T. J., Lamparski, L. L., and Crummett, W. B., Chemosphere, 16(4), 777 (1987) ; b) Kovacic, P., and Brace, N. O., J. Am. Chem. Soc., 76, 5491 (1954)

32）劉貴慶, 板谷義紀, 山崎量平, 山口正隆, 近藤元博, 森滋

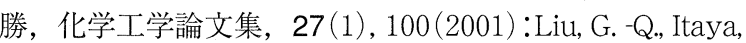
Y., Yamazaki, R., Yamaguchi, M., Kondo, M., and Mori, S., Kagaku Kogaku Ronbunsyu, 27 (1), 100 (2001) 